\title{
4f-LUMINESCENCE OF LANTHANIDE IONS IN REGIOISOMERIC
} CORROLE COMPLEXES

\section{N.N. Semenishyn ${ }^{1}$, S.S. Smola ${ }^{1}$, M.Yu. Rusakova ${ }^{2}$, N.V. Rusakova ${ }^{1}$}

${ }^{1}$ A.V. Bogatsky Physico-Chemical Institute, National Academy of Sciences of Ukraine, 86, Lustdorfs'ka doroga, Odessa 65080, Ukraine

${ }^{2}$ I.I. Mechnikov National University of Odessa, Dvoryanska 2, Odessa 65026, Ukraine

Email:ssmbikola@yahoo.com

Isomeric ditopic corroles and complexes of $\mathrm{Yb}$ (III), $\mathrm{Nd}$ (III) and $\mathrm{Er}$ (III) based on them were synthesized and corrole-photosensitized $4 f$-luminescence in near infrared region was revealed. The structure of isomeric complexes allows adjusting the distance between the corrole core and lanthanide ion. The obtained results show that the sensitization mechanism changes drastically for both different lanthanides and isomeric forms.

Keywords: lanthanides; corroles; isomers; $4 f$-luminescence; sensitization.

INTRODUCTION. In recent years, corroles and porphyrins, as separate classes of macrocyclic tetrapyrrole compounds, and their metal complexes are widely studied due to the characteristic and very intense light absorption and emission; they are also interesting as effective catalysts, as a basis for various sensors, solar panels, etc [1]. On the other hand, lanthanide compounds are in high demand primarily due to their emission features. $4 f$-Luminescence (as a result of $f$ - $f$ radiative transitions) is a particular kind of emission due to its strongly specific wavelengths for each lanthanide ion, to its lifetime (as a rule $4 f$-luminescence is a slow kind of emission and can be admitted as phosphorescence) and to a variety of regions of its appearance (UV, VIS, IR).
One of the main features of lanthanide spectroscopy is the impossibility of direct excitation of the lanthanide ion, because the $f-f$ absorption of any lanthanide ion is very weak according to the Laport rule [2]. This limitation can be easily overcome by using organic chromophores, which have efficient light absorption and the ability to transfer energy to lanthanide ions.

Macrocyclic tetrapyrroles were the first among macrocyclic compounds to reveal 4 -luminescence sensitization in the early 1970s [3-4]. Lanthanide complexes with macrocyclic tetrapyrroles are promising as agents for luminescent diagnostics (LD) [5], photodynamic therapy (PDT) [6] and magnetic resonance imaging (MRI) [7] due to their 
specific luminescent and magnetic properties. Note that $4 f$-luminescence in these complexes is possible in near-infrared (NIR) region only. Lower triplet state $\left(\mathrm{T}_{1}\right)$, which is responsible for the sensitization mechanism, can serve as an energy donor for lanthanide ions $\mathrm{Yb}^{3+}, \mathrm{Nd}^{3+}$ and $\mathrm{Er}^{3+}$, which have low-lying resonant energy levels. Sensitized $4 f$-luminescence is a quite important phenomenon, which is already used in medicine (drugs, markers, assay) [8], technology (fiber-optics, OLED), etc. NIR 4 -luminescence is highly demanded for several important reasons: the light of NIR region can penetrate biological tissues much more effectively in comparison to UV/VIS ranges $(\mathrm{UV}=$ ultraviolet, $\mathrm{VIS}=$ visual $)$ due to very poor overlapping with absorption of bioobjects; NIR light is absolutely safe for human in comparison to UV/VIS ranges whose action can generate dangerous radical species; NIR photons undergo much less scattering in comparison to UV/VIS light [9].

Since the core-coordinated complexes of lanthanides with porphyrins, corroles and phthalocyanines are somewhat less stable in comparison with cyclic and acyclic lanthanide aminopolycarboxylates, it was proposed to obtain tetrapyrrole-based ditopic compounds, which allow the lanthanide ion to be substantially coordinated by aminopolycarboxylate site $[10,11]$. This approach gave two very important achievements - outstanding stability of lanthanide-porphyrins and lanthanide-corroles and similarity in the effectiveness of both core-coordinated and side-coordinated lanthanide complexes, despite noted difference in distance between chromophore and lanthanide ion.

EXPERIMENT AND DISCUSSION OF THE RESULTS. The spectra of molecular fluorescence, 4 -luminescence and excitation spectra were recorded on a spectrofluorimeter Fluorolog FL 3-22 (Horiba Jobin Yvon) using a $450 \mathrm{~W}$ Xe-lamp. The spectra of $4 f$-luminescence of $\operatorname{Er}(\mathrm{III})$ complexes were registered in the 1500-1600 $\mathrm{nm}$ range (transition $\left.{ }^{4} \mathrm{I}_{13 / 2} \rightarrow{ }^{4} \mathrm{I}_{15 / 2}\right)$. The spectra of molecular fluorescence of porphyrins, corroles and phthalocyanines were registered at $550-800 \mathrm{~nm}\left(\mathrm{~S}_{1}-\mathrm{S}_{0}\right.$ transitions). The integral intensity of luminescence was measured using the software of the device. The relative quantum yield of molecular fluorescence $\left(\varphi_{\mathrm{ML}}\right)$ was determined using a solution of $\mathrm{Zn}$-tpp $\left(\mathrm{H}_{2}\right.$ tpp $=5,10,15,20$-tetraphenylporphyrin) in ethanol as a primary standard (0.022). The determination of $\varphi_{\mathrm{ML}}$ (accuracy $\pm 10 \%$ ) was made using the formula:

$$
\Phi_{\mathrm{ML}}=\varphi_{0} \mathrm{I}_{\mathrm{x}} \mathrm{A}_{0} \mathrm{n}_{\mathrm{x}}{ }^{2} /\left(\mathrm{I}_{0} \mathrm{~A}_{\mathrm{x}} \mathrm{n}_{0}{ }^{2}\right),
$$

where $\varphi_{0}$ and $\varphi_{\mathrm{x}}$ - luminescence quantum yield of the standard and of the sample respectively, $A_{0}$ and $A_{x}$ - absorption at the wavelength of Soret band of the standard and of the sample respectively,

$\mathrm{I}_{\mathrm{x}}$ and $\mathrm{I}_{0}$ - integral luminescence intensity of the standard and of the sample respectively, $\mathrm{n}_{0}$ and $\mathrm{n}_{\mathrm{x}}$ - refractive index of the standard solvent and of the sample solvent respectively.

Fluorescence lifetime $(\tau)$ was measured under excitation at the Soret band.

The synthesis of starting corroles $1,2,4$ and complexes 6, 8 and 10 was performed previously $[10,12]$. The purity of the obtained compounds was checked by TLC Sorbfil plates (grain 5-17 $\mu \mathrm{m}, \mathrm{UV}-254$, thickness $0.1 \mathrm{~mm}$ ) by Imid Ltd. ${ }^{1} \mathrm{H}$ NMR and ${ }^{19} \mathrm{~F}$ NMR spectra were recorded using Bruker Avance 600 or $400 \mathrm{MHz}$ in $\mathrm{CD}_{3} \mathrm{OD}$. Mass spectra (MS) were registered on the spectrometer Waters ESI TOF Premier 
and the Varian MAT CH-112 spectrometer. The elemental analysis was performed on the CHNS analyzer Flash 2000 Thermo Scientific.

\{Carboxymethyl-[2-(carboxymethyl-\{[3-(5,10-diphenyl-corrol-5-yl)-phenylcarbamoyl]-methyl\}-amino)-ethyl]-amino\}-acetic acid ( $m$ - $\mathrm{H}_{3}$ edta-corrole 3$)$.

A solution of 1 (150 mg, $0.14 \mathrm{mmol})$ in dry DMF (5 ml) was added dropwise to a stirred solution $\left(80^{\circ} \mathrm{C}\right)$ of $\mathrm{H}_{4}$ edta dianhydride $(52 \mathrm{mg}$, $0.2 \mathrm{mmol}$ ) in dry DMF ( $5 \mathrm{ml}$ ), containing a catalytic amount of triethylamine (1 drop), during 10 minutes. After adding, the reaction was continued at the same conditions for 1 hour until the starting corrole was determined by TLC in the reaction mixture. Crude product was precipitated with water, filtered and dried to provide the title compound as a purple powder in $90 \%$ yield $(185 \mathrm{mg}) .{ }^{1} \mathrm{H}$ NMR (MeOD) $\delta 9.03(\mathrm{~d}, 2 \mathrm{H}$, $\mathrm{J}=4.16 \mathrm{~Hz}), 8.83(\mathrm{~d}, 2 \mathrm{H}, \mathrm{J}=4.4 \mathrm{~Hz}), 8.69(\mathrm{~d}, 2 \mathrm{H}$, $\mathrm{J}=4.65 \mathrm{~Hz}), 8.60(\mathrm{~d}, 2 \mathrm{H}, \mathrm{J}=4.16 \mathrm{~Hz}), 8.58(\mathrm{~s}, 1 \mathrm{H})$, $7.93(\mathrm{~d}, 1 \mathrm{H}, \mathrm{J}=8.07 \mathrm{~Hz}), 7.91(\mathrm{~d}, 1 \mathrm{H}, \mathrm{J}=7.46 \mathrm{~Hz})$, $7.64(\mathrm{t}, 1 \mathrm{H}, \mathrm{J}=7.83 \mathrm{~Hz}), 3.67(\mathrm{~s}, 4 \mathrm{H}), 3.58(\mathrm{~s}, 2 \mathrm{H})$, 3.47 (s, 2H), 3.21 (s, 2H), 3.05 (s, 2H). ${ }^{19} \mathrm{~F}$ NMR (MeOD) - 140.67 (d, 2F, J=23.16Hz), -140.93 (d, $2 \mathrm{~F}, \mathrm{~J}=18 \mathrm{~Hz}),-155.67$ (t, 2F, J=17.7Hz), -164.65 $(\mathrm{t}, 2 \mathrm{~F}, \mathrm{~J}=17.7 \mathrm{~Hz}),-164.79(\mathrm{t}, 2 \mathrm{~F}, \mathrm{~J}=20.44 \mathrm{~Hz})$. ESI-MS obsd $994\left[\mathrm{M}-\mathrm{H}^{+}\right] ; \lambda_{\text {abs. }}(\mathrm{nm}(\lg \varepsilon)$, methanol) 410(5.08), 568(4.38), 615(4.26). Calc for $\mathrm{C}_{47} \mathrm{H}_{31} \mathrm{~N}_{7} \mathrm{O}_{7} \mathrm{~F}_{10}: \mathrm{C} 56.69 \%, \mathrm{H} 3.14 \%, \mathrm{~N} 9.85 \%$. Found: C 56.52\%, H 3.03\%, N 9.68\%.

Inspired by our recent findings regarding the structure features of corroles [12] and our discovery of 4 -sensitizing activity of corroles [10], in the present work we continue the synthesis and study of lanthanide complexes with these porphyrinoids, which contain strongly bound $\mathrm{Ln}^{3+}$ ion by aminopolycarboxylic site. Thus, the main idea of the present investigation is synthesis of stable lanthanide-porphyrinoids with acceptable photo-physical parameters avoiding the challenging synthesis of per-deuterated and/or per-fluorinated compounds.

NIR 4f-luminescence in coordination compounds always has poor effectiveness. Traditionally, this problem is caused by the external quenching of NIR luminescence - the overlap of NIR luminescence bands with vibrating quanta of $\mathrm{CH}$ and $\mathrm{OH}$ bonds, which are always present in the structure of the complex and the environment [13]. It is very difficult to create a system that does not contain the already mentioned chemical bonds in both the structure of the molecule and the solvent. On the other hand it is important to note that the complete removal of $\mathrm{CH}$ and $\mathrm{OH}$ bonds from the coordination environment of the lanthanide ion does not notably solve this problem [14]. The use of fully deuterated solvents does not solve this problem, too. Moreover, solutions of Er compounds in dmso and dmso-d6 do not reveal any difference in luminescence effectiveness [15]. The simultaneous use of both fully deuterated chromofores (cryptates) and fully deuterated solvents provides mediocre quantum yields of $6.1-6.6 \%$ for $\mathrm{Yb}^{3+}$ and $0.66-1.7 \%$ for $\mathrm{Nd}^{3+}$ [16]. On the other hand, fluorinated or/and deuterated ytterbium-porphyrins reveal very imposing 4 -luminescence quantum yields of up to $23 \%$ even in non-deuterated solvents (there is no data for deuterated ones) [17]. This finding does not solve the above-mentioned problem regarding stability issues. According to this study, ytterbium porphyrins decompose under irradiation with $405 \mathrm{~nm}$ light and this fact is still a remaining obstacle for in vivo use.

Since stability and luminescence effectiveness are two major requirements for lanthanide-tetrapyrroles, the above-mentioned 
approach [10-11] is the only way of solving stability issues for in vivo use.

The corrole analogue of 5,10,15,20-tetraphenylporphyrin $\left(\mathrm{H}_{2}\right.$ tpp, which is widely used as synthetically accessible and most stable) 5,10,15-triphenylcorrole $\left(\mathrm{H}_{3} \mathrm{tpc}\right)$ is a very photosensitive compound and since electron-withdrawing aryl groups increase the photostability of corroles [18], so we used a corrole with two $\mathrm{C}_{6} \mathrm{~F}_{5}$ groups and one aryl group, which could be further easily modified (Scheme 1).

5,15-Bis-(pentafluorophenyl)-10-(3-aminophenyl)-corrole 1 and 5,15-bis-(pentafluorophenyl)-10-(4-aminophenyl)-corrole 2 were obtained according to the previous data $[10$, 12]. Acylation of $\mathbf{1}$ and $\mathbf{2}$ with dianhydride of $\mathrm{H}_{4}$ edta, provides compounds 3 and 4 respectively in about $90 \%$ yield. The last step of the synthesis did not require column chromatography (Fig. 1). Ethylenediaminetetraacetic acid was chosen as binding site, since it forms very stable complexes with lanthanides, $\lg \beta=15-19$ [19].

The complexation reactions of $\mathbf{3}$ and $\mathbf{4}$ with lanthanides were performed quantitatively. Note that MALDI MS and ESI MS revealed two peaks in the molecular ion region that cor- respond to molecules with mono- and bis-adducts of $\mathrm{H}_{2} \mathrm{O}$ [10], hence corrole-edta forms peripheral complexes with two coordinated water molecules to provide the total coordination number $(\mathrm{CN})$ of lanthanide ion $\mathrm{CN}=7$. It is important to know the quantity of water molecules coordinated to the lanthanide ion since direct coordination of water to $\mathrm{Ln}^{3+}$ leads to the above energy dissipation due to overlapping of the ${ }^{4} \mathrm{~F}_{3 / 2} \rightarrow{ }^{4} \mathrm{I}_{15 / 2}$ transition $\left(5400 \mathrm{~cm}^{-1}\right)$ of $\mathrm{Nd}^{3+}$ emission with $\mathrm{O}-\mathrm{H}$ bond vibrational quanta $v=2\left(6900 \mathrm{~cm}^{-1}\right)$, and such excitation of vibrational state leads to effective quenching of the ${ }^{4} \mathrm{~F}_{3 / 2}$-state of $\mathrm{Nd}^{3+}$ ion. Overlapping of $\mathrm{O}-\mathrm{H}$ bond vibrational quanta $v=3$ with the ${ }^{2} \mathrm{~F}_{5 / 2} \rightarrow{ }^{2} \mathrm{~F}_{7 / 2}$ transition $\left(10200 \mathrm{~cm}^{-1}\right)$ of $\mathrm{Yb}^{3+}$ emission leads to the same energy dissipation.

Compounds 1 and $\mathbf{2}$ have absorption spectra that are characteristic of regular corroles like 5,10,15-tris-(pentafluorophenyl)corrole $\left(\mathrm{H}_{3} \mathrm{tpfc}\right)$. The near-UV Soret band maxima for both 1 and 2 are presented at $415(5.08) \mathrm{nm}$ (lge in parentheses), two Q-bands are in the visual range: 568 (4.38) and $615(4.26) \mathrm{nm}$ (spectra were measured in methanol). Note, that methanol solutions provide only free base forms of corroles [20].

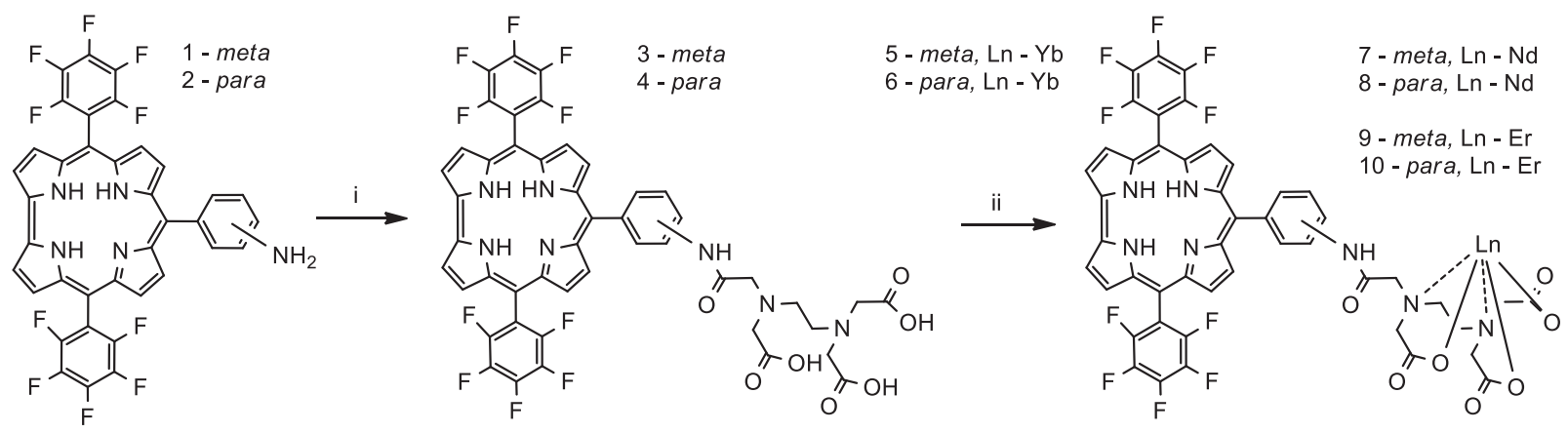

Scheme 1. Synthesis of isomeric ditopic corroles and the corresponding lanthanide complexes. i) DMF anh., $\mathrm{NEt}_{3}$ anh., $\mathrm{Ar}, \mathrm{H}_{4}$ edta dianhydride, $70-80{ }^{\circ} \mathrm{C}, 90 \%$ yield; ii) methanol, $\mathrm{RT}, \mathrm{LnCl}_{3} \mathrm{aq}$. 
Ditopic compounds 3 and $\mathbf{4}$ have exactly the same spectra: the Soret band maxima are the same for both compounds and presented at $410 \mathrm{~nm}$. Two Q-bands are the same for both compounds, too, and presented at 568 and $615 \mathrm{~nm}$. All peripheral lanthanide complexes based on $\mathbf{3}$ and $\mathbf{4}$ have the same absorption spectra: Soret band is presented at $410 \mathrm{~nm}$ and two Q-bands at 568 and $615 \mathrm{~nm}$. These similarities in light absorption features follow from the unchangeable electronic structure of chromophore. So, peripheral modification at the meta-and para-positions of phenyl at the 10 -th position by edta fragments does not affect the corrole electronic structure.

All compounds 1-10 have similar molecular fluorescence parameters: spectra, kinetic data and effectiveness. All compounds in DMF solutions provide deprotonated forms only. The maxima of S-S-emission bands are around $640-650$ and $690-700 \mathrm{~nm}$. The molecular fluorescence quantum yields $\left(\varphi_{\mathrm{ML}}\right)$ of the studied compounds are $6-10 \%$. The fluorescence lifetimes $(\tau)$ of both corroles and lanthanide-corroles in DMF and methanol solutions are 3-5 ns.

4 -Luminescence was observed in DMF and methanol solutions for all $\mathrm{Nd}, \mathrm{Yb}$ and $\mathrm{Er}$ complexes (Table 1, Fig. 1). The emission maxima are correlated with the fundamental properties of lanthanides. The $980 \mathrm{~nm}$ band of $\mathrm{Yb}$ complexes 5 and $\mathbf{6}$ were analyzed as a ${ }^{2} \mathrm{~F}_{5 / 2} \rightarrow{ }^{2} \mathrm{~F}_{7 / 2}$ transition. $\mathrm{Nd}$ complexes $\mathbf{7}$ and $\mathbf{8}$ displayed bands corresponding to ${ }^{4} \mathrm{~F}_{3 / 2} \rightarrow{ }^{4} \mathrm{I}_{9 / 2}(\approx 890 \mathrm{~nm})$ and ${ }^{4} \mathrm{~F}_{3 / 2} \rightarrow{ }^{4} \mathrm{I}_{11 / 2}$ transitions $(\approx 1060 \mathrm{~nm})$, the Er-complexes 9 and 10 emitted at $1540 \mathrm{~nm}$ due to a ${ }^{4} \mathrm{I}_{13 / 2} \rightarrow{ }^{4} \mathrm{I}_{15 / 2}$ transition (1540 nm).

Both $\mathrm{Yb}$ complexes reveal relatively weak 4 -luminescent signals, and it is hard to determine their $\varphi_{4 \mathrm{f}}$ An erbium signal at $1540 \mathrm{~nm}$ was also detected for $\mathbf{9}$ and 10, but because of the absence of references for such a far region only arbitrary units are presented.

The molecular fluorescence lifetime measurements showed that the values in methanol solutions were consistently found to be smaller than in DMF (for compounds 7 and 8, Table 1), which may be attributed to more effective vibrational accepting modes for nonradiative decay in methanol. Methanol contains strong luminescence quenching $\mathrm{O}-\mathrm{H}$ bonds, whose importance has earlier been emphasized for coordinated $\mathrm{H}_{2} \mathrm{O}$ molecules.

The obtained results indicate that the studied lanthanide-corroles are dual-range emitters (Fig.1): visual corrole-based molecular fluorescence with the most intense band at $\lambda_{\max } \approx 640-650 \mathrm{~nm}$ and $4 f$-luminescence in the NIR. This dual emission was observed at room temperature and in aerated solutions, in contrast with most other tetrapyrroles that exhibit NIR emission as phosphorescence emission only at deoxygenated conditions and usually in the frozen state (as a rule, at liquid nitrogen temperature). The distance between the paramagnetic ion and the chromophore macrocycle is so large that there is no perturbing effect of the former on the properties of the latter. Note, that this is different from the previously described core-metallated tetrapyrroles with lanthanide ions, where energy transfer from the excited chromophore to the lanthanide is quantitative and no residual fluorescence is obtained [21]. Thus, the studied side-coordinated lanthanide-corroles have non-quenched molecular fluorescence.

Strong support for the above analysis comes from the coincidence between the 4 -luminescence excitation spectra (Fig. 1) and the absorption spectra of the complexes. This clearly 
shows that IET (intramolecular energy transfer) from the donor levels of corroles (i.e., the antenna-effect) to the resonance levels of lanthanide ions takes place. One of the most important features in sensitizing $4 f$-luminescence is the energy of the lowest triplet level $\left(\mathrm{T}_{1}\right)$ of the organic chromophore - traditionally, exactly this energy level serves as a donor in IET to lanthanide ion. It can be calculated from phosphorescence spectra, and some phosphorescent metallocorroles were already reported [22-24]. Unfortunately, it was impossible to determine the $T_{1}$ levels of our compounds because free-base corroles do not phosphoresce. [25] This is also the reason that estimating the IET quantum yield is not possible at this stage.

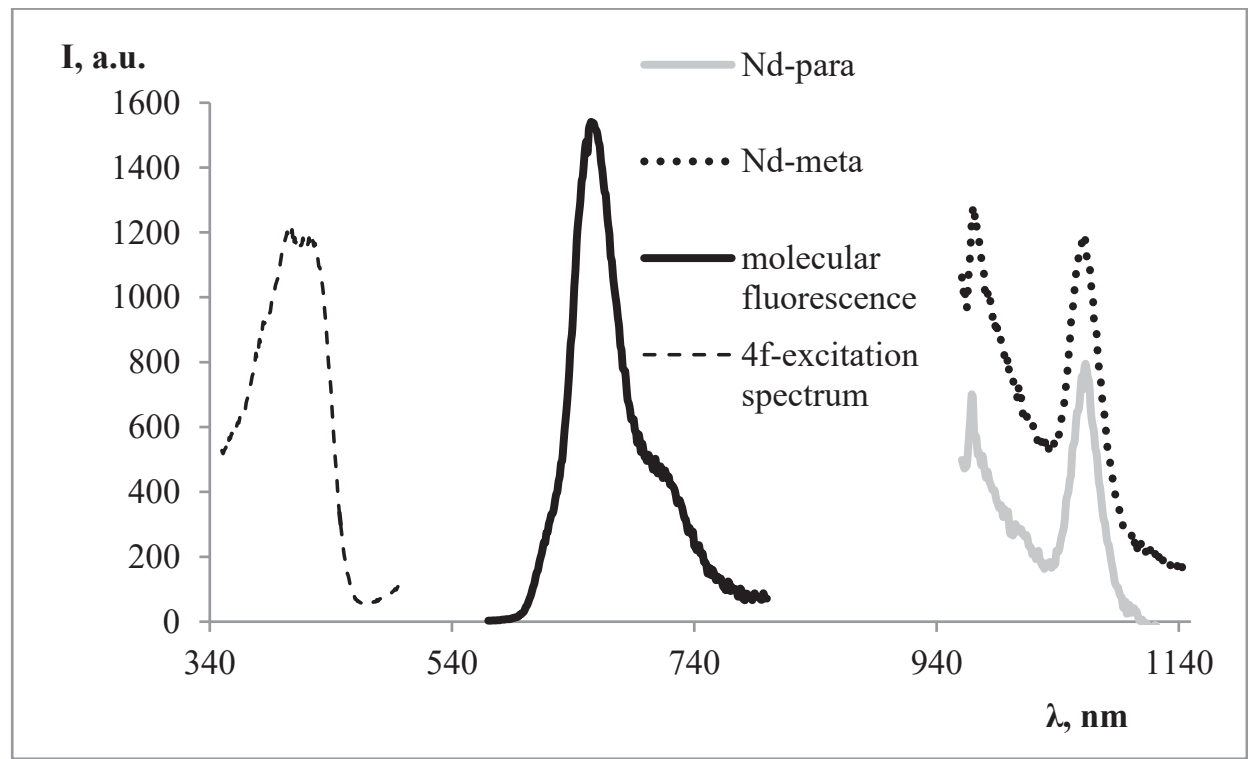

Fig.1. Excitation and emission of Nd-complexes.

Photophysical data for studied compounds

\begin{tabular}{c|c|c|c|c|c|c}
\hline$\#$ & $\begin{array}{c}\mathrm{UV} \text {-vis, nm } \\
\text { (first - Soret } \\
\text { band) }\end{array}$ & $\lambda_{\mathrm{ML}(4 \mathrm{f})}, \mathrm{nm}$ & $\mathrm{E}_{\mathrm{S} 1}, \mathrm{~cm}^{-1}$ & $\tau, \mathrm{ns}$ & $\varphi_{\mathrm{ML}} \times 10^{2^{*}}$ & $\varphi_{4 \mathrm{f}} \times 10^{3^{*}}$ \\
\hline $\mathbf{1}$ & $415,568,615$ & 643,698 & 15550 & $4.5 \pm 0.01$ & 6.8 & - \\
$\mathbf{2}$ & $415,568,615$ & 650 & 15380 & $3.47 \pm 0.01$ & 8.4 & - \\
$\mathbf{3}$ & $415,568,615$ & 643,698 & 15550 & $4.48 \pm 0.01$ & 6.7 & - \\
$\mathbf{4}$ & $410,568,615$ & 642,697 & 15580 & $3.72 \pm 0.01$ & 7.7 & - \\
$\mathbf{5}$ & $415,568,615$ & 643,698 & 15550 & $4.51 \pm 0.01$ & 6.9 & $<0.1$
\end{tabular}


Table 1

\begin{tabular}{|c|c|c|c|c|c|c|}
\hline$\#$ & $\begin{array}{l}\text { UV-vis, nm } \\
\text { (first - Soret } \\
\text { band) }\end{array}$ & $\lambda_{\mathrm{ML}(4 \mathrm{f})}, \mathrm{nm}$ & $\mathrm{E}_{\mathrm{S1}}, \mathrm{cm}^{-1}$ & $\tau, \mathrm{ns}$ & $\varphi_{\mathrm{ML}} \times 10^{2^{*}}$ & $\varphi_{4 \mathrm{f}} \times 10^{3^{*}}$ \\
\hline 6 & $410,568,615$ & 638,696 & 15670 & $3.21 \pm 0.02$ & 9.7 & $<0.1$ \\
\hline 7 & $415,568,615$ & 638,696 & 15670 & $4.2 \pm 0.01$ & 6.8 & 4.7 \\
\hline $7^{\star *}$ & $415,568,615$ & 638,696 & 15670 & $4.1 \pm 0.01$ & 5.9 & 1.0 \\
\hline 8 & $410,568,615$ & $\begin{array}{c}639,695 \\
(891,1061)\end{array}$ & 15650 & $3.43 \pm 0.02$ & 7.6 & 2.79 \\
\hline $8^{\star *}$ & $410,568,615$ & $\begin{array}{c}636 \\
(890,1061)\end{array}$ & 15720 & $3.20 \pm 0.01$ & 4.7 & 0.5 \\
\hline 9 & $415,568,615$ & 638,696 & 15670 & $4.5 \pm 0.01$ & 6.7 & $18500^{x+x+x}$ \\
\hline 10 & $410,568,615$ & $\begin{array}{c}639,695 \\
(1540)\end{array}$ & 15650 & $3.53 \pm 0.01$ & 9.2 & $20000^{x+x+x}$ \\
\hline Zn-tpp ${ }^{\#}$ & 425 & 604,659 & 16560 & $2.07 \pm 0.01$ & 2.2 & - \\
\hline
\end{tabular}

All solutions with oxygen, DMF, RT, $\lambda_{\text {exc. }}=410 \mathrm{~nm}, \mathrm{C}=10^{-5} \mathrm{M}$.

${ }^{*} \pm 10 \%$; ${ }^{* *}$ methanol solution; ${ }^{* *} \varphi_{4 \mathrm{f}}$ for $\mathrm{Nd}^{3+}$ was calculated for only ${ }^{4} \mathrm{~F}_{3 / 2} \rightarrow{ }^{4} \mathrm{I}_{9 / 2}$ transition; ${ }^{* * * *}$ arbitrary units; ${ }^{*}$ Data from [26-27].

It can be assumed that in theory, the $4 f$-sensitization of $\mathrm{Yb}^{3+}$ ion can pass through two transitions: the traditional $\mathrm{T}_{1} \rightarrow^{2} \mathrm{~F}_{5 / 2}$ and presumably $\mathrm{S}_{1} \rightarrow{ }^{2} \mathrm{~F}_{5 / 2}$. [28]. The low level of the $\mathrm{Yb}^{3+}$ 4 -luminescent signal in such compounds is attributed to poor contribution of the $\mathrm{T}_{1} \rightarrow{ }^{4} \mathrm{~F}_{3 / 2}$ transition in 4 -sensitization mechanism for both compounds 5 and $\mathbf{6}$. On the other hand, both the molecular fluorescence and intersystem crossing lifetime of corroles (as well as for porphyrins) is too short and the transition $\mathrm{S}_{1} \rightarrow{ }^{2} \mathrm{~F}_{5 / 2}$ seems to be not competitive compared to $S_{1} \rightarrow S_{0}$ ( $\tau$ is around 3-5 ns) and $S_{1} \rightarrow T_{n}$ ( $\tau$ is around $10 \mathrm{~ns}$ ) at least because of the absence of any kind of direct chemical bonding between donor and acceptor (direct binding allows very fast transitions - just picoseconds). Another very important reason of the very low contribution of this transition is the almost full absence of overlapping of donor emission ( $\lambda$ range $580-780 \mathrm{~nm}$ ) and acceptor absorption ( $\lambda$ range 870-1020 nm). On the other hand neodymium-corroles 7 and 8 have perceptible $\varphi_{4 \mathrm{f}}$ values. In this case, the contribution of the $\mathrm{S}_{1} \rightarrow^{4} \mathrm{~F}_{3 / 2}$ resonant transition should rise because of the good overlapping of donor emission ( $\lambda$ range $580-780 \mathrm{~nm}) \mathrm{E}_{\mathrm{S} 1}=15670 \mathrm{~cm}^{-1}$ and acceptor absorption ( $\lambda$ range $570-590 \mathrm{~nm}$ ). We'd like to underline that like in the case of $\mathrm{Yb}^{3+}$, the resonant transition $\mathrm{S}_{1} \rightarrow{ }^{4} \mathrm{~F}_{3 / 2}$ is thermodynamically allowed since corrole $\mathrm{E}_{\mathrm{S} 1}=15670 \mathrm{~cm}^{-1}$ and neodymium $\mathrm{E}_{4 \mathrm{~F} 3 / 2}=11700 \mathrm{~cm}^{-1}$. The contribution of $\mathrm{T}_{1} \rightarrow{ }^{4} \mathrm{~F}_{3 / 2}$ stays unknown, but we can speculate that similarly to $\mathrm{Yb}$ complexes, it is very low. 
Isostructural lanthanide-porphyrins (and all other complexes with lanthanides) have an opposite feature: the $\varphi_{4 \mathrm{f}}$ values of ytterbium complexes are always higher than their isostructural neodymium analogues.

The spatial position of the energy acceptor ion relative to the corrole chromofore in the case of ytterbium (para- or meta-regioisomers) does not matter in terms of its emission effectiveness. Per contra, neodymium emission is sensitive to the spatial arrangement of ion relative to the chromofore, in other words, neodymium emission is sensitive to the distance between donor and acceptor. It is an additional proof for the domination of the $\mathrm{S}_{1} \rightarrow{ }^{4} \mathrm{~F}_{3 / 2}$ sensitizing transition in neodymium-corroles. Thus, the meta-isomer of neodymium-corrole has a $\varphi_{4 \mathrm{f}}$ value, which is 2 times higher than that for para-isomer.

CONCLUSIONS. Isomeric ditopic corroles and isostructural complexes of $\mathrm{Yb}$ (III), $\mathrm{Nd}$ (III) and Er (III) based on them were synthesized. The obtained results show that neodymium luminescence is particular in neodymium-corroles complexes. This work additionally confirms the previous assumption regarding the $4 f$-sensitization mechanism pathway in these compounds. Neodymium emission is notably sensitive to the spatial position of the ion relative to the chromofore.

\section{ACKNOWLEDGEMENTS}

The authors acknowledge the support from the Targeted Program of Basic Research of the National Academy of Sciences of Ukraine (State registration № 0120U100133).
4f-ЛЮМІНЕСЦЕНЦІЯ ЮНІВ ЛАНТАНІДВВ У РЕГІОІЗОМЕРНИХ КОМПЛЕКСАХ ІЗ КОРОЛАМИ

М. М. Семенішин ${ }^{*}$, С. С. Смола ${ }^{1}$, М. Ю. Русакова ${ }^{2}$ Н. В. Русакова

1 Фізико-хімічний інститут ім. О. В. Богатського НАН України, 86, вул. Люстдорфська дорога, м. Одеса 65080, Украӥна

${ }^{2}$ Одеський національний університет ім. I. I. Мечникова, вул. Дворянська 2, м. Одеса 65026, Україна

*e-mail:ssmbikola@yahoo.com

Синтезовано ізомерні дитопні короли та комплекси Yb (III), Nd (III) та Er (III) на їній основі та виявлено корол-фотосенсибілізовану $4 f$-люмінесценцію в ближній інфрачервоній області. Структура ізомерних комплексів дозволяє регулювати відстань між ядром королу та іоном лантаноїду. Отримані результати показують, що механізм сенсибілізації різко змінюється як для різних лантаноїдів, так і для різних ізомерних форм.

Ключові слова: лантаноїди; короли; ізомери; 4f-люмінесценція; сенсибілізація.

\section{REFERENCES}

1. Ageeva T.A., Koifman O. I., Beletskaya I. P., Averin A. D., Yakushev A. A., Tomilova L. G., Dubinina T. V., Tsivadze A. Yu., Gorbunova Yu. G., Martynov A. G., Konarev D. V., Khasanov S. S., Lyubovskaya R. N., Lomova T. N., Korolev V. V., Zenkevich E. I., Blaudeck T., BorczyskowskiC.D., Zahn R.T., Mironov A.F., 
Bragina N. A., Ezhov A. V., Zhdanova K. A., Stuzhin P. A., Pakhomov G. L., Rusakova N. V., Semenishyn N. N., Smola S. S., Parfenyuk V. I., Vashurin A. S., Makarov S. V., Dereven'kov I. A., Mamardashvili N. Zh., Kurtikyan T. S., Martirosyan G. G., Burmistrov V. A., Aleksandriiskii V. V., Novikov I. V., Pritmov D. A., Grin M. A., Suvorov N. V., Tsigankov A. A., Fedorov A. Yu., Kuzmina N. S., Nyuchev A. V., Otvagin V. F., Kustov A. V., Belykh D. V., Berezin D. B., Solovieva A. B., Timashev P. S., Milaeva E. R., Gracheva Yu. A., Dodokhova M. A., Safronenko A. V., Shpakovsky D. B., Syrbu S. A., Gubarev Yu. A., Kiselev A. N., Koifman M. O., Lebedeva N. Sh., Yurina E. S. Macroheterocyclic Compounds - a Key Building Block in New Functional Materials and Molecular Devices. Macroheterocycles. 2020. 13 (4): 311-467.

DOI: $10.6060 / \mathrm{mhc} 200814 \mathrm{k}$.

2. Laporte O., Meggers W.F. Some Rules of Spectral Structure*. J. Opt. Soc. Am. 1925. 11 (5): 459-463. DOI: 10.1364/josa.11.000459

3. Kachura T. F., Sevchenko A. N., Solov'ev K. N., Tsvirko M. P. Intramolecular transfer of electron excitation energy in porphyrin complexes of ytterbium. Dokl. Phys. Chem. 1974. 217 (5): 1121-1124 (In Russian).

4. Gouterman M., Schumaker C.D., Srivastava T.S., Yonetani T. Absorption and luminescence of yttrium and lanthanide octaethylporphin complexes. Chem. Phys. Lett. 1976. 40 (3): 456-461.

DOI: 10.1016/0009-2614(76)85118-4.

5. Tsvirko M., Korovin Y., Rusakova N.. Ytterbium-porphyrins as a new class of the luminescent labels. Journal of Physics: Conference Series. 2007. 79. 012025.

DOI: 10.1088/1742-6596/79/1/012025.

6. Zang L., Zhao H., Hua J., Qin F., Zheng Y., Zhang Z., Cao W. Water-soluble gadolinium porphyrin as a multifunctional theranostic agent: Phosphorescence-based oxygen sensing and photosensitivity. Dyes and Pigments.
2017. 142: 465-471.

DOI: 10.1016/j.dyepig.2017.03.056

7. Tsolekile N., Nelana S., Oluwafemi O.S. Porphyrin as Diagnostic and Therapeutic Agent. Molecules. 2019. 24 (14): 2669.

DOI: $10.3390 /$ molecules24142669.

8. Kaczmarek M. Lanthanide-sensitized luminescence and chemiluminescence in the systems containing most often used medicines; a review. J. Luminescence. 2020. 222117174. DOI: 10.1016/j.jlumin.2020.117174.

9. Martinić I., Eliseeva S.V., Petoud S. Near-infrared emitting probes for biological imaging: Organic fluorophores, quantum dots, fluorescent proteins, lanthanide(III) complexes and nanomaterials. J. Luminescence. 2017. 189 19-43. DOI: 10.1016/j.jlumin.2016.09.058.

10. Semenishyn N., Gross Z. Lanthanide-corrole conjugates. Dalton Trans. 2013. 42 (11): 3775-3778. DOI: 10.1039/c2dt32842a.

11. Kuznetsova R.T., Ermolina E.G., Gadirov R.M., Mayer G.V., Semenishin N.N., Rusakova N.V., Korovin Y.V. Luminescence of metal complexes of chelate-substituted tetraphenylporphyrin. High Energy Chemistry. 2010. 44 (2): 134-138.

DOI: $10.1134 / \mathrm{s} 0018143910020098$.

12. Semenishyn N.N., Ognichenko L.N., Smola S.S., Rusakova N.V. Regioisomers of Mononitro- and Monoamino-A2B-Corroles: Synthesis and Unusual Luminescence Behavior. ChemistrySelect. 2019. 4 (35): 10340-10345. 10.1002/slct.201902777.

13. Yanagida S., Hasegawa Y., Murakoshi K., Wada Y., Nakashima N., Yamanaka T.. Strategies for enhancing photoluminescence of $\mathrm{Nd} 3+$ in liquid media. Coord. Chem. Rev. 1998. 171 (0): 461-480.

DOI: 10.1016/S0010-8545(98)90069-8.

14. Foley T.J., Harrison B.S., Knefely A.S., Abboud K.A., Reynolds J.R., Schanze K.S., Boncella J.M. Facile Preparation and Photophysics of Near-Infrared Luminescent Lanthanide(III) Monoporphyrinate Complexes. 
Inorg. Chem. 2003. 42 (16): 5023-5032.

DOI: $10.1021 / \mathrm{ic034217g.}$

15. Klink S.I., Hebbink G.A., Grave L., Veggel F.C.J.M.V., Reinhoudt D.N., Slooff L.H., Polman A., Hofstraat J.W. Sensitized near-infrared luminescence from polydentate triphenylene-functionalized $\mathrm{Nd} 3+, \mathrm{Yb} 3+$, and Er3+ complexes. Journal of Applied Physics. 1999. 86 (3): 1181-1185. DOI: 10.1063/1.370867.

16. Doffek C., Alzakhem N., Molon M., Seitz M. Rigid, Perdeuterated Lanthanoid Cryptates: Extraordinarily Bright Near-IR Luminophores. Inorganic Chemistry. 2012. 51 (8): 4539-4545. DOI: 10.1021/ic202376k.

17. Ning Y., Tang J., Liu Y.-W., Jing J., Sun Y., Zhang J.-L. Highly luminescent, biocompatible ytterbium(III) complexes as near-infrared fluorophores for living cell imaging. Chemical Science. 2018. 9 (15): 3742-3753. DOI: 10.1039/C8SC00259B.

18. Geier G.R., Chick J.F.B., Callinan J.B., Reid C.G., Auguscinski W.P. A Survey of Acid Catalysis and Oxidation Conditions in the TwoStep, One-Flask Synthesis of Meso-Substituted Corroles via Dipyrromethanedicarbinols and Pyrrole. J. Org. Chem. 2004. 69 (12): 4159-4169. DOI: 10.1021/jo0496493.

19. Alexander V. Design and Synthesis of Macrocyclic Ligands and Their Complexes of Lanthanides and Actinides. Chem. Rev. 1995. 95 (2): 273-342. DOI: 10.1021/cr00034a002.

20. Kruk M., Ngo T.H., Savva V., Starukhin A., Dehaen W., Maes W. Solvent-Dependent Deprotonation of meso-Pyrimidinylcorroles: Absorption and Fluorescence Studies. J. Phys. Chem. A. 2012. 116 (44): 10704-10711.

DOI: $10.1021 /$ jp305327c.

21. Semenishyn N. N., Rusakova N. V., Mazepa A. V, Korovin Yu. V. Synthesis of Ditopic Porphyrins and Lanthanide Complexes on their Basis: Luminescent Features. Macroheterocycles. 2009. 2 (1): 57-59.

DOI: $10.6060 / \mathrm{mhc} 2009.1 .57$.

22. Nardis S., Mandoj F., Paolesse R., Fronczek
F.R., Smith K.M., Prodi L., Montalti M., Battistini G. Synthesis and Functionalization of Germanium Triphenylcorrolate: The First Example of a Partially Brominated Corrole. Eur. J. Inorg. Chem. 2007. 2007 (16): 23452352. DOI: 10.1002/ejic.200700184.

23. Palmer J.H., Durrell A.C., Gross Z., Winkler J.R., Gray H.B. Near-IR Phosphorescence of Iridium(III) Corroles at Ambient Temperature. J. Am. Chem. Soc. 2010. 132 (27): 92309231. DOI: $10.1021 /$ ja101647t.

24. TanabeM., MatsuokaH.,OhbaY., YamauchiS., Sugisaki K., Toyota K., Sato K., Takui T., Goldberg I., Saltsman I., Gross Z. Time-Resolved Electron Paramagnetic Resonance and Phosphorescence Studies of the Lowest Excited Triplet States of Rh(III) Corrole Complexes. J. Phys. Chem. A. 2012.116 (39): 9662-9673. DOI: 10.1021/jp3071037.

25. Ventura B., Degli Esposti A., Koszarna B., Gryko D.T., Flamigni L. Photophysical characterization of free-base corroles, promising chromophores for light energy conversion and singlet oxygen generation. New J. Chem. 2005. 29 (12):

DOI: 1559-1566. 10.1039/B507979A.

26. Stel'makh G.F., Tsvirko M.P. Influence of the aggregated state and temperature on the spectral-fluorescent properties of Zn-tetraphenylporphin. J. Appl. Spectrosc. 1983. 39 (3): 1041-1046. DOI: 10.1007/bf00659041.

27. Kowalska D., Steer R.P. Quenching of MgTPP and ZnTPP fluorescence by molecular oxygen. J. Photochem. Photobiol., A. 2008. 195 (2-3): 223-227.

DOI: 10.1016/j.jphotochem.2007.10.011.

28. Semenishyn N.N., Rusakova N.V. Study of Structure--Properties Relationship for Lanthanide Tetrapyrrolic Macrocycles Modified with Aminopolycarboxylate Substituents. Macroheterocycles. 2016. 9 (2): 163-168. DOI: $10.6060 / \mathrm{mhc} 160425 \mathrm{r}$.

Стаття надійшла 30.09.2021. 